\title{
Late Glacial and Holocene aeolian sands and soil formation from the Pomeranian outwash plain [Mecklenburg, NE-Germany]
}

\author{
Dedicated to the 75th birthday of Wolfgang Janke
}

Mathias Küster, Frank Preusser

Abstract:

\begin{abstract}
The nature, duration and intensity of Late Glacial and Holocene aeolian sand and soil formation is established for two dune profiles from the Pomeranian outwash plain using a multidisciplinary approach (sedimentology, pedology, palynology, geochronology). During the Late Glacial period, coversands accumulated as thin sheets on plateau areas of the outwash plain, interrupted by the formation of the Finow soil. The spreading of dense vegetation cover during the Early Holocene resulted in stabilisation of the landscape surface and subsequent soil formation. After intensive medieval deforestation, surface destabilisation caused partial reworking of the coversands, resulting in the formation of dunes and a hummocky topography. One of the dunes investigated formed entirely within the Late Subatlantic. This study highlights the spatial and temporal variability of aeolian activity in areas where suitable grain sizes were made available during different periods after deglaciation.
\end{abstract}

[Spätglaziale und holozäne Flugsande und Bodenbildungen aus dem Pommerschen Sandergebiet [Mecklenburg, NEDeutschland]]

\begin{abstract}
Kurzfassung: $\quad$ Anhand von zwei Dünenprofilen wird die Art, Dauer und Intensität von spätglazialen und holozänen Flugsand- und Bodenbildungen innerhalb des Pommerschen Sandergebietes dargestellt. Hierfür wurde ein interdisziplinärer Ansatz aus Sedimentologie, Pedologie, Palynologie und Geochronologie verwendet. Während des Spätglazials kommen auf den Sanderhochflächen flache Flugsanddecken zur Ablagerung, unterbrochen durch die Bildung des Finowbodens. Durch die Ausbreitung einer geschlossenen Vegetationsdecke im Frühholozän, erfolgt eine Stabilisierung der Reliefoberfläche mit anschließender Bodenbildung. Nach intensiven mittelalterlichen Rodungen werden die Oberflächen erneut destabilisiert. Es kommt zur partiellen Aufarbeitung der Flugsande resultierend in Dünenbildungen und einem kuppigen Relief. Eine der untersuchten Dünen wurde dabei komplett im späten Subatlantikum gebildet. Diese Studie unterstreicht die zeitlich-räumliche Variabilität äolischer Aktivität, wobei Umlagerungen entsprechender Korngrößen während verschiedener Phasen nach der Deglaziation ermöglicht wurden
\end{abstract}

Key words: aeolian sands, Finow Soil, fossil soils, Late Glacial, Holocene dune formation, Geschiebedecksand (GDS)

Addresses of authors: M. Küster, University of Greifswald, Institute of Geography and Geology, Friedrich-Ludwig-Jahn-Straße 16, D-17487 Greifswald. E-Mail: mathias.kuester@uni-greifswald.de; F. Preusser, University of Bern, Institute of Geological Sciences, Baltzerstrasse 1+3, CH-3012 Bern

\section{Introduction}

Throughout the European sand belt fossil soils of different age provide evidence of surface stability, while aeolian deposits mirror phases of morphodynamic activity (SCHIRMER 1999a). Comprehensive stratigraphic investigations in the adjacent areas of northern Brandenburg, Schleswig-Holstein and Poland resulted in a conceptional model for the timing of aeolian phases in northern Central Europe (MANiKowsKA 1991; Teschner-Steinhardt \& MÜLler 1994; Bussemer et al. 1998; MÜLLER 1999, 2000; MAUZ et al. 2005, HiLGERS 2007). Previous studies in Mecklenburg-Vorpommern have largely focussed on the coastal region (JANKE 1971; KLIEWE \& JANKE 1978; KAISER et al. 2006), and investigations from the inland are rare (e.g., DiecKMANN \& KAISER 1998). This paper contributes to filling this gap by presenting new results on the chronology of aeolian processes and soil formation within the Pomeranian outwash plain.

\section{Study area}

The study area is situated on the Pomeranian outwash plain, between the ice-marginal zones of the Frankfurt Phase
(18.4 ka BP) and the Pomeranian Phase (15.2 ka BP, Marks 2002). Despite its overall southern slope, the outwash plain offers a differentiated geomorphology, comprising older till areas, numerous kettle holes and meltwater channels. The latter depressions, which reflect glaciofluvial sedimentation between and over melting dead ice during Weichselian deglaciation (NITZ 1984), were subsequently filled with lakes and fens. Areas of dunes and aeolian coversands supplement the geomorphic inventory. The profiles investigated here (BF-1 and ZW-1) are part of dune complexes which are situated south of the village Blankenförde (Fig. 1), and are built up of widespread coversands and dune bodies with a hummocky morphology (KüsTER et al. 2008).

\section{Methods}

Fieldwork consisted of digging the pits manually, cleaning the faces and describing soil and sediment properties following the guidelines of the AD-HOC-AG BodEN ( KA 5, 2005). Colours were determined according to MUNSELL-COLORCHART. The content of organic material was measured by loss on ignition (LOI) at $550{ }^{\circ} \mathrm{C}$ for 2 hours. The soil $\mathrm{pH}$ was determined in $0.01 \mathrm{M} \mathrm{CaCl}_{2}$. The grain size distribution of 


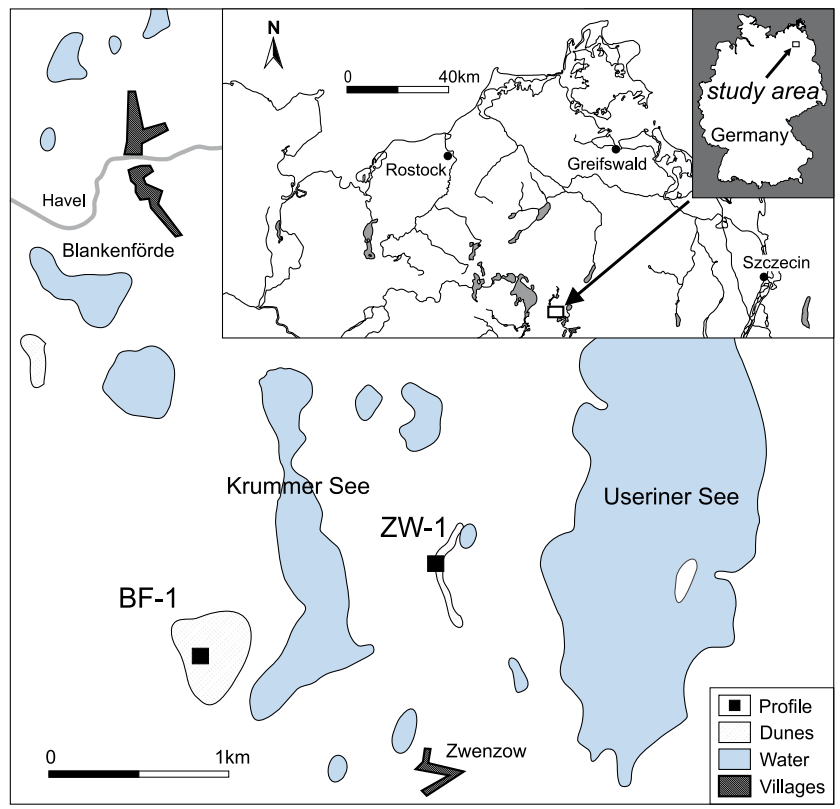

Fig. 1: Location of the study area in northeast Germany.

Abb. 1: Lage des Untersuchungsgebietes in Nordostdeutschland.

the fraction $\leq 2 \mathrm{~mm}$ was determined by a combined sieve and sedimentation procedure (KöHN 1928). Element concentrations (sample $+\mathrm{LiBo}_{2}(2 \mathrm{~g})+\mathrm{Li}_{2} \mathrm{Bo}_{4} \mathrm{O}_{7}(1,9320 \mathrm{~g})$ ) were measured using a Phillipps PW 2404 RFA-spectrometer. Weathering indices were calculated based on the element molar-ratios (RuXton 1968; Kronberg \& NesbitT 1981; HARNOIS 1988). Pollen samples were separated by acetolyses (BEUG 2004) and non-aboreal pollen (NAP) were related to the amount of 100 tree pollen. A radiocarbon sample (Erl12081) was determined by the AMS-laboratory Erlangen using charcoal and calibrated using CALIB 5.0 (STUIVER et al. 2005). Ages are given as years before present (1000 a = $1 \mathrm{ka})$ and are correlated with the chronology recently summarised by LiTT et al. (2007).

Optically stimulated luminescence (OSL) dating of quartz $(150-200 \mu \mathrm{m})$ was carried out using a modified Single Aliquot Regenerative Dose (SAR) protocol (MURRAY \& WINTLE, 2000). A preheat temperature of $230^{\circ} \mathrm{C}$ for $10 \mathrm{~s}$ prior to all OSL measurements was identified as appropriate from the results of SAR performance testes. Equivalent dose and standard error were calculated from the mean of replicate measurements (no indication for partial bleaching or postdepositional mixing). The concentration of dose rate relevant elements was determined by high-resolution low-level gamma spectrometry (Tab. 1). Sampling depth (for cosmic dose rate) and present sediment moisture have been used for dose rate calculation.

\section{Results}

\section{Profile BF-1}

This profile has been divided into three units that will be described in stratigraphical order (Fig. 2).

\section{Unit I}

The basal part of the section consists of non-stratified sands. The grain size distribution reveals a homogenous sediment unit of fine and medium sand with very sporadic fine gravel. The top of Unit I is made up of a brownish, root penetrated soil horizon (2Bwb) of fine and medium sand, with a higher amount of gravel, silt and clay than the underlying sediments. Prominent pebbles at its base show traces of aeolian polishing. Because of the stratigraphical position and the lithology this sediment is classified as "Geschiebedecksand" (GDS) following German terminology (BERENDT 1863). Together with the non-stratified sands below, this unit is interpreted as a periglacial cover bed (LEMBKE 1972). As typically for most other parts of NE-Germany, the GDS coincides with a brownish soil horizon (KopP et al. 1969, KopP 1970; BusSEMER 2005). Because of missing stratified basal sediments a periglacial cover bed with perstruction zones is not documented (Kopp et al. 1969; KopP \& JÄGER 1972). The weathering indices highlight the brownish soil horizont as the main weathering zone (Tab. 2). OSL-dating (MN 584) of this horizon yields an age of $15.5 \pm 1.0 \mathrm{ka}$.

\section{Unit II}

The middle unit of the dune profile is made up of homogenous sands, dominated by medium and fine sands. With decreasing depth a decrease of the fine sand fraction is observed, while the fractions of medium sand, silt and clay increase. A fossil Cambisol (IUSS Working Group WRB 2006) separates Unit I from Unit II. The organic content (LOI) is prominent in the buried humic horizon (Apb), but less dominant than for the modern humic horizon (Unit III), due to the advanced mineralisation. The Bwb-horizon, comprising diffusely distributed charcoal fragments, shows a lower LOI value. The weathering indices characterise the brownish horizon as the second main weathering zone within the profile. Because of its facies character Unit II is classified as aeolian

Table 1: Summary data of OSL dating with concentration of dose rate relevant elements $(K, T h, U)$, sediment water content, resulting dose rate, equivalent dose $\left(D_{E}\right)$ and OSL age.

Tab 1: Zusammenfassung der OSL-Datierungen mit Konzentration der für die Dosisleistung relevanten Elemente (K, Th, U), Sediment-Wassergehalt, resultierende Dosisleistung $\left(D_{E}\right)$ und OSL-Alter.

$\begin{array}{lllllllll}\text { Sample } & \mathbf{K} & \begin{array}{l}\text { Th } \\ {[\%]}\end{array} & \begin{array}{l}\text { U } \\ {[\mathrm{ppm}]}\end{array} & \begin{array}{l}\text { W } \\ {[\%]}\end{array} & \begin{array}{l}\text { Depth } \\ {[\mathrm{m}]}\end{array} & \begin{array}{l}\text { D } \\ {[\mathrm{Gy} \text { ka-1 }]}\end{array} & \begin{array}{l}\text { DE } \\ {[\mathrm{Gy}]}\end{array} & \begin{array}{l}\text { OSL age } \\ {[\mathrm{ka}]}\end{array} \\ & & & & & & & & \\ \text { MN582 } & 0.88 \pm 0.02 & 2.13 \pm 0.13 & 0.59 \pm 0.02 & 4 \pm 1 & 1.70 & 1.25 \pm 0.05 & 17.3 \pm 0.9 & 13.8 \pm 0.9 \\ \text { MN583 } & 0.88 \pm 0.02 & 2.32 \pm 0.06 & 0.65 \pm 0.01 & 4 \pm 1 & 1.75 & 1.28 \pm 0.05 & 17.3 \pm 0.6 & 13.5 \pm 0.7 \\ \text { MN584 } & 0.93 \pm 0.02 & 7.56 \pm 0.17 & 1.30 \pm 0.03 & 8 \pm 1 & 1.80 & 1.76 \pm 0.07 & 27.3 \pm 1.4 & 15.5 \pm 1.0\end{array}$




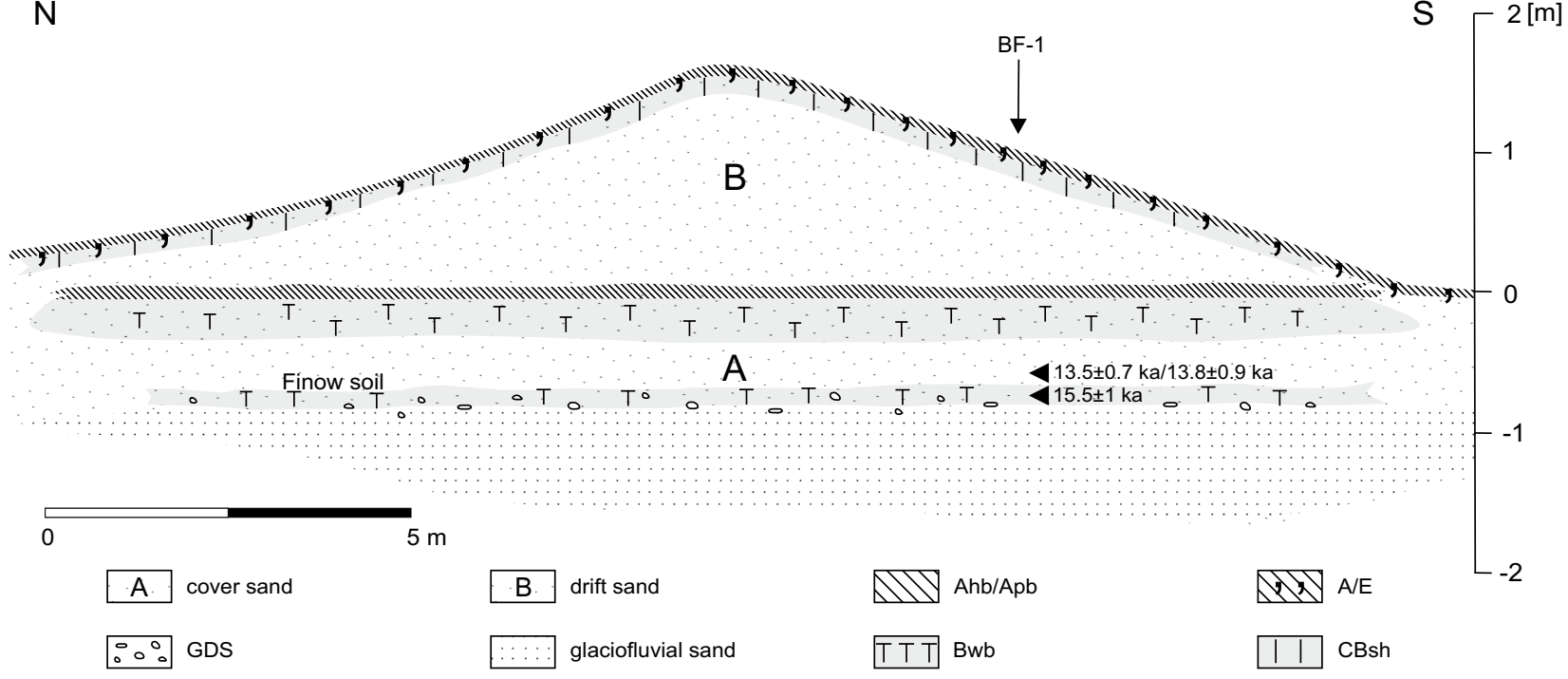

Unit Pedo Pedo Colour LOI $\quad \mathrm{pH} \quad$ Grain size distribution [\%]

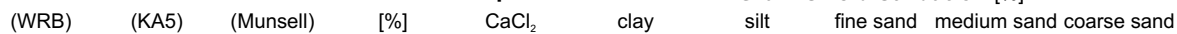

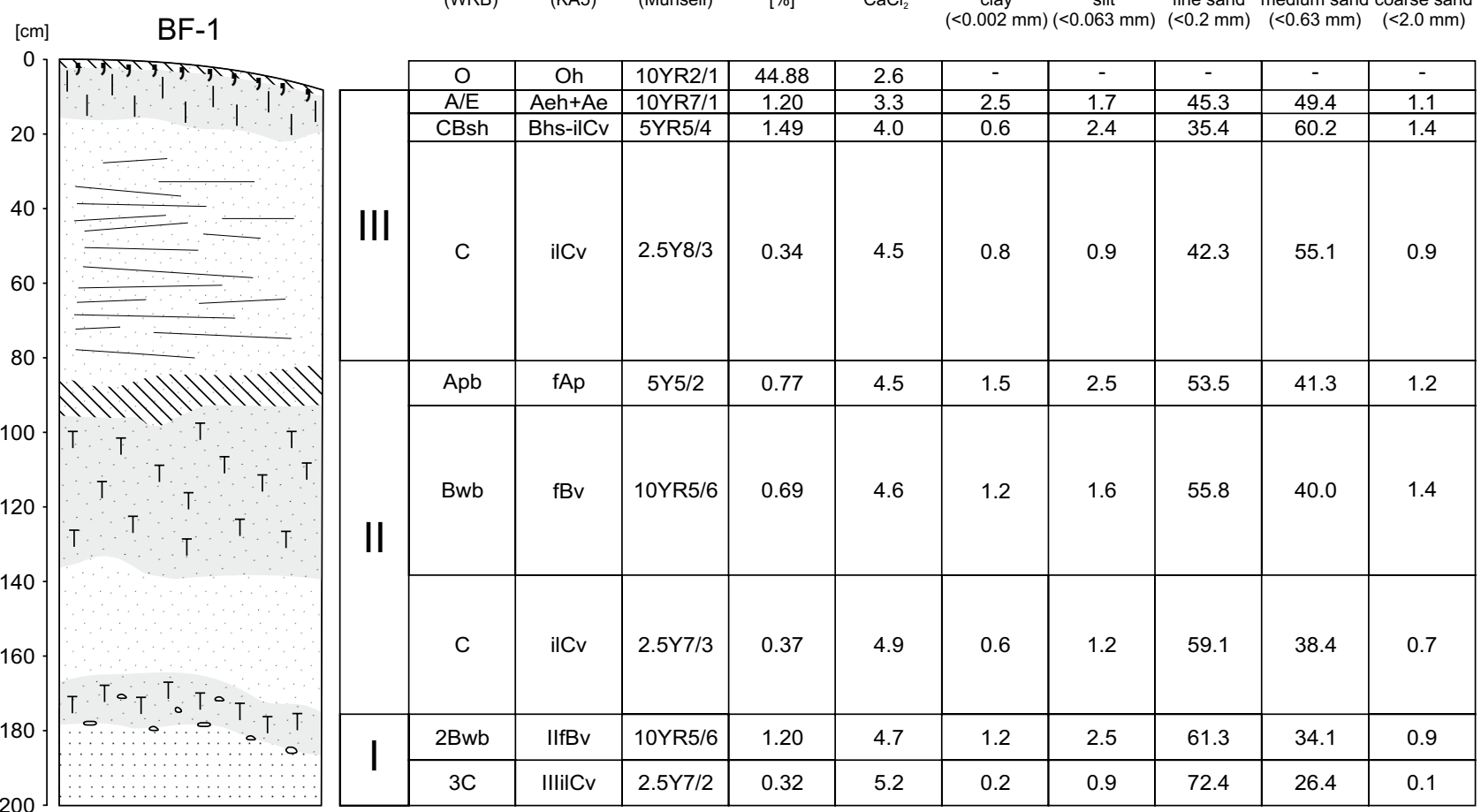

Fig. 2: Cross-section through a sequence of aeolian sands of the plateau areas and pedological parameters of profile BF-1 (modified from KüSTER et al. 2008). Abb. 2: Profilschnitt durch eine Flugsandsequenz der Hochflächen und pedologische Parameter des Profils BF-1 (verändert nach KüsTER et al. 2008).

coversand (SCHIRMER 1999b). Two samples obtained from the base of this unit yield OSL ages of $13.8 \pm 0.9 \mathrm{ka}$ (MN 582) and $13.5 \pm 0.7 \mathrm{ka}$ (MN 583), respectively. Pollen samples from the fossil humic horizon (Apb) indicate an open, deforestated landscape, reflected by a high proportion of non-tree-pollen, such as Artemisia, Calluna vulgaris and Plantago lanceolata (Fig. 3). The abundence of species such as Secale and Scleranthus implies intensive agricultural use in the surroundings, palynologically dating the horizon to the Late Subatlantic (Xb, FIRBAS 1949).

\section{Unit III}

The grain size distribution of Unit III is dominated by medium sand and subordinate fine sand. With decreasing depth an increase in silt and clay is recognised, like in the un- derlying complex. The partly observed horizontal, slightly inclined bedding indicates sediment accumulation as lowangle aeolian deposits (FrYBerger et al. 1979). Despite the relatively low maximum thickness of $1.8 \mathrm{~m}$, the sand unit creates an intensive hummocky topography, a feature regionally known as "Kuppendüne" (PYritz 1972).

The upper part of Unit III is characterized by a podzolized Arenosol (IUSS WORKING Group WRB 2006) or a Podsol-Regosol (AD-Hoc-AG Boden 2005). Despite the weak development of the soil, the advanced differentiation into an eluvial and an illuvial horizon, reflected in both colour and loss on ignition values, indicate a final state of a transformation to a podzol (LundSTRÖm et al. 2000; BEHRENDT et al. 2002). Pollen analyses of the O-horizon suggests a closed forest vegetation during the time of soil formation. Based on the rapid decrease of non-tree-pollen compared to the Apb horizon and 

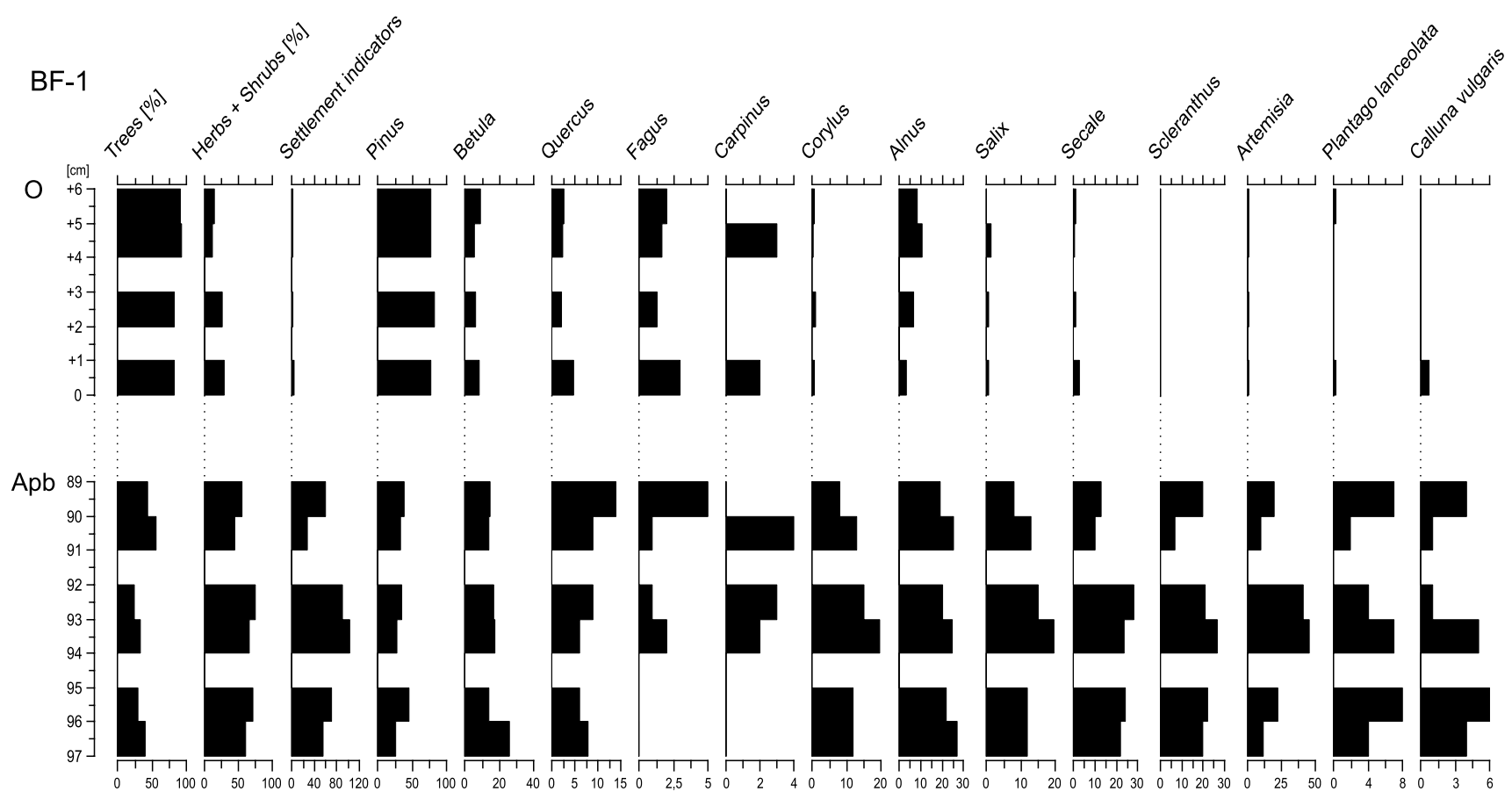

Fig. 3: Selected pollen data from humic horizons of profile BF-1. / Abb. 3: Ausgewählte Pollendaten aus Humushorizonten des Profils BF-1.

the dominance of Pinus sylvestris, it can reasonably be assumed that a vegetation cover established during the Youngest Subatlantic (Xc, FirBAS 1949).

\section{Profile ZW-1}

Alongside the western margin of a peat filled depression a linear dune was investigated, comprising profile $\mathrm{ZW}-1$ (Fig. 4). The basal part shows a fossil Cambisol (IUSS WorkING Group WRB 2006). High LOI values and a widespread occurrence of charcoal indicate an intensive anthropogenic impact. The exceptionally thick fossil humic horizon can be separated into three parts (Apb). Each part reflects a separate phase of aeolian sedimentation and, due to agricultural use (ploughing), ends on a sharp upper limit to aeolian sand which are free of humus. A charcoal sample at the bottom of the humic horizon reveals a radiocarbon age of $815 \pm 44{ }^{14} \mathrm{C}$ yr BP (1154-1280 AD, 97,4\%-2 $\sigma$ calibrated, STUIVER et al. 2005) and provides a maximum age for the onset of aeolian activity. It can thus be concluded that the entire dune was formed during the Late Subatlantic, representing a "Holocene dune"
(Dulias 1999). At the top a weakly podzolized Arenosol (IUSS WorkING GROUP WRB 2006) represents the result of modern soil formation.

\section{Discussion}

Deposition of glaciofluvial sands in the area terminated during the Late Pleniglacial, prior $15 \mathrm{ka}$ ago, as indicated by the OSL date for the basal part of the sections. The following Late Glacial period is set between the Mecklenburg Phase and the middle Preboreal (KLIEwe 2004). The periglacial cover bed of profile BF-1 (Unit I) provides evidence of intensive cryogenic, postsedimentary modification of the plateau-sites. The genesis of the "Geschiebedecksand" (GDS) as the central element of periglacial cover beds has been discussed in detail, and the relevant key elements are discussed below. On sandy slopes within the Weichselian periglacial belt solifluction, nival runoff, concurrent winnowing of fines (abluation sensu LIEDTKE (1990)) and aeolian processes are the main processes involved in its formation (BusSEMER et al. 1993). For the plateau sites Kopp et al. (1969), Kopp (1970), Kopp \& JÄGER

Table 2: Major element analysis and chemical weathering indices of profile BF-1 (soil horizons according to IUSS WORKING GROUP WRB 2006).

Tab. 2: Hauptelementanalyse und chemische Verwitterungsindizes des Profils BF-1 (Bodenhorizonte nach IUSS WORKING GROUP WRB 2006).

\begin{tabular}{|c|c|c|c|c|c|c|c|c|c|c|c|c|c|c|}
\hline Horizon & $\mathrm{SiO}_{2}$ & $\mathrm{Al}_{2} \mathrm{O}_{3}$ & $\mathrm{Fe}_{2} \mathrm{O}_{3}$ & $\mathrm{MnO}$ & $\mathrm{MgO}$ & $\mathrm{CaO}$ & $\mathrm{Na}_{2} \mathrm{O}$ & $\mathrm{K}_{2} \mathrm{O}$ & $\mathrm{P}_{2} \mathrm{O}_{5}$ & $\mathrm{TiO}_{2}$ & Ruxton (1968) & \multicolumn{2}{|c|}{ Kronberg \& Nesbitt (1981) } & Harnois (1988) \\
\hline & {$[\%]$} & {$[\%]$} & {$[\%]$} & {$[\%]$} & {$[\%]$} & {$[\%]$} & {$[\%]$} & {$[\%]$} & {$[\%]$} & {$[\%]$} & $\mathrm{SiO}_{2} / \mathrm{Al}_{2} \mathrm{O}_{3}$ & Ordinate & Abscissa & CIW \\
\hline $\mathrm{A} / \mathrm{E}$ & 91.89 & 2.34 & 0.47 & 0.01 & 0.06 & 0.21 & 0.43 & 0.93 & 0.02 & 0.23 & 66.61 & 0.47 & 0.99 & 68.12 \\
\hline CBsh & 89.60 & 2.43 & 0.64 & 0.01 & 0.08 & 0.21 & 0.43 & 0.94 & 0.05 & 0.23 & 62.55 & 0.47 & 0.98 & 68.83 \\
\hline $\mathrm{C}$ & 92.66 & 2.70 & 0.70 & 0.02 & 0.10 & 0.25 & 0.50 & 0.98 & 0.05 & 0.31 & 58.34 & 0.46 & 0.98 & 67.92 \\
\hline Apb & 92.56 & 2.74 & 0.56 & 0.02 & 0.09 & 0.22 & 0.57 & 0.99 & 0.06 & 0.19 & 57.37 & 0.47 & 0.98 & 67.30 \\
\hline Bwb & 92.24 & 3.07 & 0.58 & 0.01 & 0.09 & 0.22 & 0.49 & 1.02 & 0.06 & 0.19 & 51.01 & 0.43 & 0.98 & 72.03 \\
\hline C & 91.79 & 2.89 & 0.65 & 0.02 & 0.11 & 0.27 & 0.55 & 1.07 & 0.05 & 0.21 & 53.81 & 0.47 & 0.98 & 67.49 \\
\hline $2 \mathrm{Bwb}$ & 89.43 & 4.31 & 0.85 & 0.02 & 0.14 & 0.26 & 0.51 & 1.16 & 0.06 & 0.28 & 35.21 & 0.37 & 0.97 & 76.70 \\
\hline $3 C$ & 92.85 & 2.86 & 0.65 & 0.02 & 0.11 & 0.25 & 0.48 & 1.09 & 0.02 & 0.20 & 55.14 & 0.46 & 0.98 & 69.55 \\
\hline
\end{tabular}




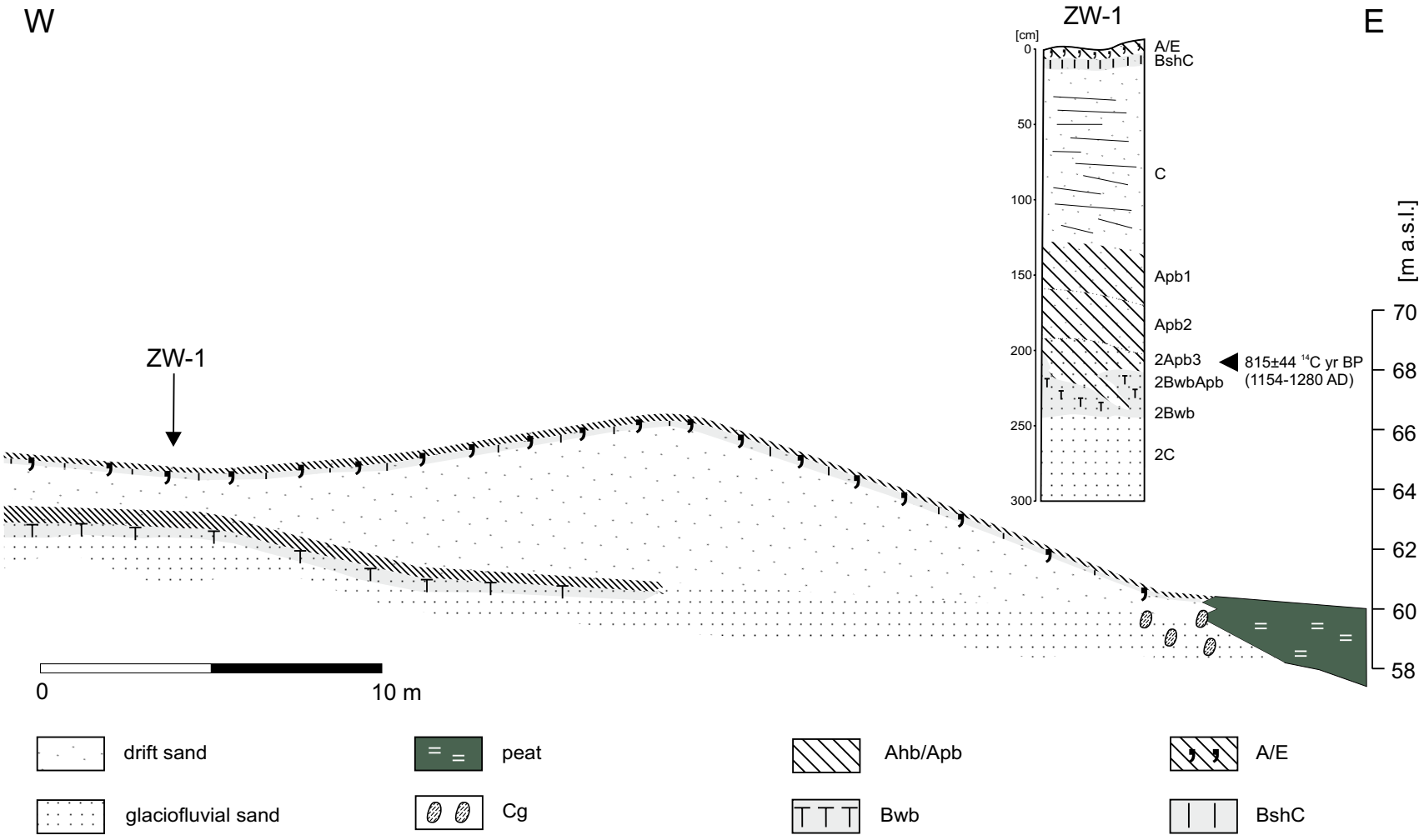

Fig. 4: Cross-section through a Holocene dune and pedology of profile ZW-1 (soil horizons according to IUSS WORKING GROUP WRB 2006).

Abb. 4: Profilschnitt durch eine holozäne Düne und Pedologie des Profils ZW-1 (Bodenhorizonte nach IUSS WORKING GROUP WRB 2006).

(1972) and Kopp \& KowALKOwski (1990) favour cryogenic destratification as the main formation process for the GDS. These authors describe this process as a post- or synsedimentary - in situ - modification of the sediment matrix under periglacial conditions. The gravel-bed at its base with ventifacts represents a desert pavement indicating deflation and is a prevalent phenomenon in glacial landscapes of NE-Germany (LEMBKE 1972). In terms of genetic processes, the "Beuningen Gravel Bed” (BGB), which is widespread in western Europe and forms an important marker horizon in the Late Weichselian coversand stratigraphy (VANDENBERGHE 1985, KASSE 2002), might be a close correlative to the clast pavements observed here. While Kolstrup (1980) suggests a twophase development for the BGB with a fluvial phase causing deposition of coarse sand and gravel followed by a deflation phase, KASSE et al. (2007) consider a synsedimentary fluvioaeolian regime. The formation of the BGB has been dated to the Late Pleniglacial (c.14-18 ka, KASSE et al. 2007).

The non-stratified glaciofluvial sands at Blankenförde suggest a relative enrichment of gravel on the surface due to frost heave under permafrost conditions after glaciofluvial sedimentation, thereby destroying former glaciofluvial sediment structures (FRENCH 2007). This phase was most likely followed by an aeolian phase causing deflation of fine materials and modification of gravel to ventifacts (Fig. 5).

For the final formation of the GDS Bussemer (2002) assumes processes including sedimentation and cryogenic destratification of sediments. At this juncture the (coarse) silt content of the GDS gives evidence of aeolian sedimentation, typical within regions of sandy plains (ALTERMAnN 1970). Therefore the charakter of the GDS as a parautochthonous facies can be stressed (BUSSEMER 2002). OSL dating (MN 584) of the GDS sediments indicates a Late Pleniglacial to Late Glacial age.

Within the GDS a weakly developed Cambisol was identified, which is parallelised with the Finow soil, which has widespread occurrence in Brandenburg (Germany) (SCHLAAK 1993, 1998, 1999, Bussemer et al. 1998). Occurences of this palaeosol were reported from Poland and MecklenburgVorpommern (KowALKOWSKI et al. 1999; LoRENZ et al. 2002; KAISER 2003, KAISER et al. 2009). For the Netherlands, NWGermany, the Altdarss area of Mecklenburg-Vorpommern (southern Baltic coast) and central Poland a stratigraphically identical but pedologically different soil was found, the Usselo soil (HijSzeler 1957; DüCKER \& MAARLEveld 1957; KASSE 1999; KAISER \& ClaUSEN 2005; KAISER et al. 2006). It is classified as a weakly podzolized Arenosol (IUSS WorkING Group WRB 2006) or a weakly podzolized Regosol (AD-HOCAG BoDEN 2005). There is no sufficient explanation for the apparent provenances of both palaeosols so far. A compilation of 63 ages from Usselo and Finow soils in northern Central Europe reveals a substantial time range for soil formation between the Older Dryas and the Younger Dryas, with single outliers in the Preboreal (KAISER et al. 2009). Hence, formation of these palaeosols can based on geochronological data not securely be correlated to the Allerød, as often assumed, and it is more appropriate to interpret these soils as being of Late Glacial age (KAISER et al. 2009). The two consistent OSL ages (MN 582 and MN 583) of the overlying Unit II of Profil BF-1 indicate that the Finow soil at Blankenförde was fossilized at least $\sim 13.5 \mathrm{ka}$ ago by Late Glacial aeolian activity.

Palynological records from Lake Müritz provide evidence of an increasing vegetation cover within the Mecklenburg 
Lake District during the Preboreal (LAmpe et al. 2009), implying successive stabilisation of the surface at Blankenförde after Late Glacial sediment translocation, i.e. since the Early Holocene. Therefore the increasing silt content within Unit II (and Unit III, profile BF-1) is interpreted as reflecting a decrease in wind strength due to a closing vegetation cover (Dücker \& MaArleveld 1957). The fossil Cambisol at the top of Unit II reflects a subsequent surface stability (RoHDENBURG 1970) enabling soil formation within Late Glacial aeolian substrate. Because of its minor thickness compared to undisturbed Cambisols, a phase of soil erosion of unknown age, prior to the formation of the buried humic horizon (Apb), is assmued. The absolute values of weathering indices document a lower weathering intensity compared to the time of Late Glacial palaeosol formation, possibly due to higher Late Glacial climate variability or/and a higher initial degree of weathering of the blown-out parent material. Biogenic mixing during soil formation is well documented by the absence of sedimentary structures, diffusely distributed charcoal fragments and a slightly lower content of organic matter of the Bwb-horizon compared to the humic horizon (Apb) above (ANDERSEn 1979; Helbig et al. 2002). However, a syndepositional character of the charcoal could also be assumed. Pollen analysis of the fossil humic horizon reveals a partly open landscape, indicating intensive deforestation during Medieval Times, reflecting the maximum age of the aeolian sands on top (LüDERs 1961). Most likely, Late Holocene human landscape disturbance led to an interruption of soil formation, causing sediment translocations in the sense of soil erosion (BORK 1988). Late Glacial coversands were reworked resulting in the formation of new dunes.The facies of these Young Holocene aeolian sands can be classified as drift sands (CASTEL et al. 1989; CASTEl 1991; Koster et al. 1993), and the onset of this youngest aeolian phase can be placed into the $13^{\text {th }}$ century (profile $\mathrm{ZW}-1$ ). Within profile
BF-1 the increasing content of medium sand, with a concurrent decrease in the content of fine sand, provides evidence of the selective effect of successive deflation processes: coarse grain sizes are relatively enriched, whereas fine grains are depleted (Goossens \& GROss 2002). This was followed by Late Holocene soil formation, which can be classified in the study area as a weakly podzolized Arenosol (IUSS WoRKING Group WRB 2006). For the maritime influenced Denmark STÜTZER (1998) concludes a rate of podzolization within aeolian sands of $1 \mathrm{~cm}$ per decade. Taking the thickness of the podzolic horizons of soil formation into account, a remarkably lower rate is recorded in the study area, probably due to its more subcontinental character.

\section{Conclusions}

The "Geschiebedecksand" (GDS) on sandy plateau sites as a stratigraphic marker in NE-Germany is of periglacial origin due to frost heave, deflation, aeolian sedimentation and finally destratification. The timing oft its formation seems comparable with the Beuningen Gravel Bed in western Europe. The Late Glacial Finow soil developed in GDS and was buried by Late Glacial coversands about 13.5 ka ago. Afterwards, a long phase of surface stablility lasted until the Late Holocene. Pollen analyses of humic horizons give evidence of intensive human impact (mainly deforestation) during the Medieval, causing soil erosion and reshaping of the morphology at the plain sites. A phase of dune sand accumulation post dating the $13^{\text {th }}$ century provides evidence of strong human impact at around this time.

\section{Acknowledgements}

First of all we have to thank Prof. Dr. W. Janke for the pollen analyses and helpful advice and Prof. Dr. R. Lampe (Greifs-

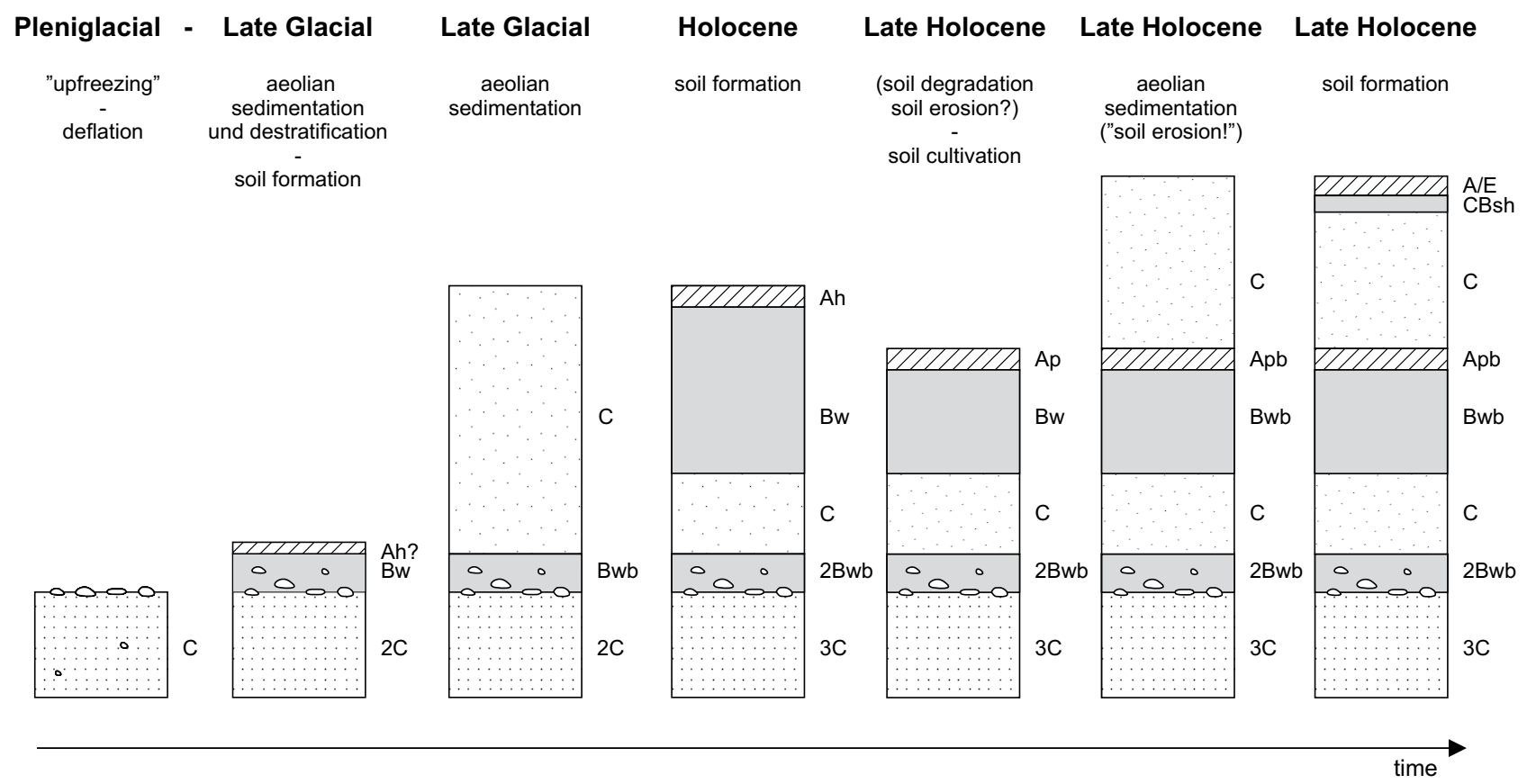

Fig. 5: Genesis of profile BF-1 including sedimentary processes and soil formation (soil horizons according to IUSS WORKING GROUP WRB 2006).

Abb. 5: Genese des Profils BF-1 einschließlich sedimentologischer Prozesse und Bodenbildung (Bodenhorizonte nach IUSS WoRKING GROUP WRB 2006). 
wald) for financial support for OSL dating. Michael Naumann (Greifswald) prepared the OSL samples at Bern and Dr. Sönke Szidat (Bern) carried out the gammaspectrometric analyses. Many thanks to F. Idler (Güstrow), H. Rabe and S. Seefeldt (Greifswald) for the laboratory and logistical support. We thank Dr. Sven Lukas (London) for the improvement of the English and fruitful advice, and Dr. Johanna Lomax as well as Dr. Walter Grottenthaler for reviewing this article.

\section{References}

AD-Hoc-AG Boden (2005): Bodenkundliche Kartieranleitung. 5. Auflage. 438 S.; Hannover (BGR).

Altermann, M. (1970): Periglaziale Decksedimente. In: Richter, H., HaAse, G., Lieberoth, I. \& Ruske, R. (eds.): Periglazial-Löß-Paläolithikum im Jungpleistozän der DDR. - Petermanns Geographische Mitteilungen, Ergänzungsheft, 274: 232-250.

ANDERSEN, S.T. (1979): Brown earth and podzol: soil genesis illuminated by microfossil analysis. - Boreas, 8: 59-73.

Behrendt, A., KaffKe, A. \& Mundel, G. (2002): Ein fossiler Podsol in Brandenburg - Ursachen seiner Entstehung und ein Vergleich zu seinem Folgeboden. - Archiv für Acker- und Pflanzenbau und Bodenkunde, 48: 213-226.

Berendt, G. (1863): Die Diluvialablagerungen in der Mark Brandenburg. Zeitschrift der deutschen geologischen Gesellschaft, 15: 640-642.

Beug, H.-J. (2004): Leitfaden der Pollenbestimmung für Mitteleuropa und angrenzende Gebiete. - 542 S.; München (Pfeil Verlag).

Bork, H.-R. (1988): Bodenerosion und Umwelt - Verlauf, Ursachen und Folgen der mittelalterlichen und neuzeitlichen Bodenerosion. Bodenerosionsprozesse. Modelle und Simulation. - Landschaftsgenese und Landschaftsökologie, 13: 249 S.

Bussemer, S. (2002): Periglacial cover-beds in the young moraine landscape in northern Eurasia. - Zeitschrift für Geomorphologie, N. F. Suppl.-Bd., 127: 81-105.

Bussemer, S. (2005): Die Braunerde in ihrer nordbrandenburgischen Typusregion. Brandenburgische geowissenschaftliche Beiträge, 12/1-2: 3-12.

Bussemer, S., GÄrtner, P. \& SchlaAK, N. (1993): Neue Erkenntnisse zur Beziehung von Relief und geologischem Bau der südlichen baltischen Endmoräne nach Untersuchungen auf der Neuenhagener Oderinsel. Petermanns Geographische Mitteilungen, 137: 227-239.

Bussemer, S., Gärtner, P. \& SchlaAk, N. (1998): Stratigraphie, Stoffbestand und Reliefwirksamkeit der Flugsande im brandenburgischen Jungmoränenland. - Petermanns Geographische Mitteilungen, 142: $115-125$.

CASTEL, I.I.Y. (1991): Micromorphology of the transition peat - Holocene drift sand deposits in the northern Netherlands. - Zeitschrift für Geomorphologie, N. F. Suppl.-Bd., 90: 29-43.

Castel, I., Koster, E. \& Slotboom, R. (1989): Morphogenetic aspects and age of Late Holocene eolian drift sands in Northwest Europe. Zeitschrift für Geomorphologie, N. F., 33: 1-26.

Dieckmann, O. \& KaIser, K. (1998): Pedologische und geomorphologische Befunde zur historischen Bodenerosion im Müritz-Nationalpark (Mecklenburg-Vorpommern). - In: Asmus, I, PoradA, H.T., SchleinERT, D. (eds.): Geographische und historische Beiträge zur Landeskunde Pommerns. - Sonderband der Greifswalder Geographischen Arbeiten: 59-67.

DüCKer, A. \& MAARLEveld, G.C. (1957): Hoch- und spätglaziale äolische Sande in Nordwestdeutschland und in den Niederlanden. - Geologisches Jahrbuch, 73: 215-234.

Dulias, R. (1999): Holocene dunes in southern Poland. In: Schirmer, W. (ed.): Dunes and fossil soils. - GeoArchaeoRhein, 3: 137-146 ; Münster (LIT).

Firbas, F. (1949): Die spät- und nacheiszeitliche Waldgeschichte Mitteleuropas nördlich der Alpen. Bd. 1: Allgemeine Waldgeschichte. - 480 S.; Jena (Fischer Verlag).

French, H.M. (2007): The Periglacial Environment. 3rd Edition. - 478 S.; Chichester (Wiley).

Fryberger, S.G., Ahlbrandt, T. S. \& Andrews, S. (1979): Origin, sedimentary features, and significance of low-angle eolian "sand sheet" deposits, Great Dunes National Monument and Vicinity, Colorado. - Journal of Sedimentary Petrology, 49/3: 733-746.
Goossens, D. \& Gross, J. (2002): Similarities and dissimilarities between the dynamics of sand and dust during wind erosion of loamy sandy soil. - Catena, 47: 269-289.

HARnOIs, L. (1988): The CIW Index: A new chemical index of weathering. Sedimentary Geology, 55: 319-322.

Helbig, H., De Klerk, P. Kühn, P. \& Kwasniowski, J. (2002): Colluvial sequences on till plains in Vorpommern (NE Germany). - Zeitschrift für Geomorphologie, N. F. Suppl.-Bd., 128: 81-100.

HiJszeler, G.C.W.J. (1957): Late-glacial human cultures in the Netherlands. - Geologie en Mijnbouw, 19: 288-302.

Hilgers, A. (2007): The chronology of Late Glacial and Holocene dune development in the northern Central European lowland reconstructed by optically stimulated luminescence (OSL) dating. Phd-Thesis. University of Cologne.

IUSS WORKING GROUP WRB (2006): World reference base for soil resources 2006. 2nd edition. World Soil Resources Reports No. 103.: 145 S.; Rome (FAO)

JANKe, W. (1971): Beitrag zu Entstehung und Alter der Dünen der Lubminer Heide sowie der Peenemünde-Zinnowitzer Seesandebene. - Wissenschaftliche Zeitschrift der Universität Greifswald, MathematischNaturwissenschaftliche Reihe, 20,1/2: 39-54.

KAISER, K. (2003): Geoarchäologie und landschaftsgeschichtliche Aussage spätpaläolithischer und frühmesolithischer Fundplätze in MecklenburgVorpommern. - Meyniana, 55: 49-72.

Kaiser, K. \& Clausen, I. (2005): Palaeopedology and stratigraphy of the Late Palaeolithic Alt Duvenstedt site, Schleswig-Holstein (NorthwestGermany). - Archäologisches Korrespondenzblatt, 35: 447-466.

Kaiser, K., Barthelmes, A., Czakó Pap, S., Hilgers, A., Janke, W., KühN, P. \& Theuerkauf, M. (2006): A Lateglacial palaeosol cover in the Altdarss area, southern Baltic Sea coast (northeast Germany): investigations on pedology, geochronology and botany. - Netherlands Journal of Geosciences 85/3: 197-220.

Kaiser, K., Hilgers, A., Schlaak, N., Jankowski, M., Kühn, P., BusseMer, S. \& PrzegietKa, K. (2009): Palaeopedological marker horizons in northern central Europe: characteristics of Lateglacial Usselo and Finow soils. - Boreas, 38: 591-609.

Kasse, C. (1999): Late Pleniglacial and Late Glacial aeolian phases in The Netherlands. - In: Schirmer, W. (ed.): Dunes and fossil soils. - GeoArchaeoRhein, 3: 61-82; Münster (LIT).

Kasse, C. (2002): Sandy aeolian deposits and environments and their relation to climate during the Last Glacial Maximum and Lateglacial in northwest and central Europe. - Progress in Physical Geography, 26: 507-532.

Kasse, C., Vandenberghe, J., De Corte, F. \& van den Haute, P. (2007) Late Weichselian fluvio-aeolian sands and coversands of the type locality Grubbenvorst (southern Netherlands): sedimentary environments, climate record and age. - Journal of Quaternary Science, 22/7: 695-708.

KLIEwe, H. (2004): Weichsel-Spätglazial. - In: KAtzunG, G. (ed.): Geologie von Mecklenburg-Vorpommern. - S. 242-251; Stuttgart (Schweizerbart).

Kliewe, H. \& JANKe, W (1978): Zur Stratigraphie und Entwicklung des nordöstlichen Küstenraumes der DDR. - Petermanns Geographische Mitteilungen, 122/ 2: 81-91.

KöHN, M. (1928): Bemerkungen zur mechanischen Bodenanalyse: III. Ein neuer Pipettapparat. - Zeitschrift für Pflanzenernährung, Düngung, Bodenkunde, 11: 50-54.

Kolstrup, E. (1980): Climate and stratigraphy in northwestern Europe between $30.000 \mathrm{BP}$ and $13.000 \mathrm{BP}$, with special reference to the Netherlands. - Mededelingen Rijks Geologische Dienst, 32/15: 181-253.

Kopp, D. (1970): Kryogene Perstruktion und ihre Beziehung zur Bodenbildung im Moränengebiet. - In: Richter, H., HaAse, G., Lieberoth, I. \& Ruske, R. (eds.): Periglazial-Löß-Paläolithikum im Jungpleistozän der DDR. - Petermanns Geographische Mitteilungen, Ergänzungsheft, 274: 269-279.

Kopp, D. et al. (1969): Ergebnisse der forstlichen Standortkartierung in der Deutschen Demokratischen Republik. Potsdam.

Kopp, D. ひ JÄGER, K.-D. (1972): Das Perstruktions- und Horizontprofil als Trennmerkmal periglaziärer und extraperiglaziärer Oberflächen im nordmitteleuropäischen Tiefland. - Wissenschaftliche Zeitschrift der Universität Greifswald, Mathematisch-Naturwissenschaftliche Reihe, 21/1: 77-84.

Kopp, D. $\mho$ KowALKowski, A. (1990): Cryogenic and pedogenic perstruction in tertiary and quaternary deposits, as exemplified in the outcrop of Sternebeck. - Quaternary studies in Poland, 9: 51-71. 
Koster, E. A., CAStel, I. I. Y. \& NAP, R. L. (1993): Genesis and sedimentary structures of late Holocene aeolian drift sands in northwest Europe. - In: Pye, K. (ed.): The dynamics and environmental context of aeolian sedimentary systems. - Geological Society Special Publication, 72: 247-267; London (Geological Society).

Kowalkowski, A., NowaczyK, B. ひ OKuniewska-NowaczyK, I. (1999): Chronosequence of biogenic deposits and fossil soils in the dune near Jasień, Western Poland. - In: Schirmer, W. (ed.): Dunes and fossil soils. - GeoArchaeoRhein, 3: 107-127; Münster (LIT).

Kronberg, B.I. \& NesBitT, H.W. (1981): Quantification of weathering, soil geochemistry and soil fertility. - Journal of Soil Science, 32: 453-459.

Küster, M., Janke W., LAmpe, R., Lorenz, S., Meyer, H. \& Naumann, M. (2008): Rekonstruktion holozäner Bodenerosion anhand von Kolluvien, Flugsanddecken und Seesedimenten im Sander des Pommerschen Stadiums (NO-Deutschland). - Abhandlungen der Geologischen Bundesanstalt, 62: 173-177.

Lampe, R., Lorenz, S., Janke, W., Meyer, H., Küster, M. Hübener, T. \& Schwarz, A. (2009): Zur Landschafts- und Gewässergeschichte der Müritz. Umweltgeschichtlich orientierte Bohrungen 2004-2006 zur Rekonstruktion der nacheiszeitlichen Entwicklung. - In: Nationalparkamt Müritz (ed.): Forschung und Monitoring, Band 2, 94 S.; Greifswald (Geozon).

Lembke, H. (1972): Die Periglazialerscheinungen im Jungmoränengebiet der DDR. - Wissenschaftliche Zeitschrift der Universität Greifswald, Mathematisch-Naturwissenschaftliche Reihe, 21/1: 71-76.

Liedtke, H. (1990): Abluale Abspülung und Sedimentation in Nordwestdeutschland während der Weichsel-(Würm)-Eiszeit. - In: LiedtKe, H. (ed.): Eiszeitforschung: 261-269; Darmstadt (Wissenschaftliche Buchgesellschaft).

Litt, T., Behre, K.-E., Meyer, K.-D., Stephan, H.-J. \& Wansa, S. (2007) Stratigraphische Begriffe für das Quartär des norddeutschen Vereisungsgebietes. - Quaternary Science Journal, 56/1-2: 7-65.

Lorenz, S., Rother, H. \& KAISER, K. (2002): Die jungquartäre Gewässernetzentwicklung der Krakower Seen und der Nebel (Mecklenburg) erste Ergebnisse. - Greifswalder Geographische Arbeiten, 26: 79-82.

LÜDERS, R. (1961): Altersbestimmung an einem doppelten Podsolprofil aus dem Emsland. - Zeitschrift für Pflanzenernährung, Düngung, Bodenkunde, 94: 47-53.

Lundström, U.S., van BREEMAN, N. \& BAIN, D. (2000): The podzolization process. A review. - Geoderma, 94: 91-107.

ManikowsKA, B. (1991): Vistulian and Holocene aeolian activity, pedostratigraphy and relief evolution in Central Poland. - Zeitschrift für Geomorphologie, N.F. Suppl.-Bd., 90: 131-141.

MArks, L. (2002): Last Glacial Maximum in Poland. - Quaternary Science Reviews, 21: 103-110.

Mauz, B., Hilger, W., Müller, M.J., Zöller, L. ש Dikau, R. (2005): Aeolian activity in Schleswig-Holstein (Germany): Landscape response to Late
Glacial climate change and Holocene human impact. - Zeitschrift für Geomorphologie, N.F. 49: 417-431.

MÜLlER, M.J. (1999): Genese und Entwicklung schleswig-holsteinischer Binnendünen. - Berichte zur deutschen Landeskunde, 73: 129-150.

MüLLER, M.J. (2000): Altersbestimmung an schleswig-holsteinischen Binnendünen mit Hilfe von Paläoböden. - Trierer Bodenkundliche Schriften,1: 23-31.

Murray, A.S. \& Wintle, A.G. (2000): Luminescence dating of quartz using an improved single-aliquot regenerative-dose protocol. - Radiation Measurements, 32: 57-73.

Nitz, B. (1984): Grundzüge der Beckenentwicklung im mitteleuropäischen Tiefland - Modell einer Sediment- und Reliefgenese. - Petermanns Geographische Mitteilungen, 128: 133-142.

PyriTZ, E. (1972): Binnendünen und Flugsandebenen im Niedersächsischen Tiefland. - Göttinger Geographische Abhandlungen, 61: 1-153.

Rohdenburg, H. (1970): Morphodynamische Aktivitäts- und Stabilitätszeiten statt Pluvial- und Interpluvialzeiten. - Eiszeitalter u. Gegenwart, 21: 81-96.

Ruxton, B.P. (1968): Measures of the degree of chemical weathering of rocks. - Journal of Geology, 76: 518-527.

Schirmer, W. (1999a): Dune phases and fossil soils in the European sand belt. - In: Schirmer, W. (ed.): Dunes and fossil soils. - GeoArchaeoRhein, 3: 11-42; Münster (LIT).

Schirmer, W. (1999b): Definitions concerning coversand, fossil soil and paleosol. - In: Schirmer, W. (ed.): Dunes and fossil soils. - GeoArchaeoRhein, 3: 187-190; Münster (LIT).

SchlAAK, N. (1993): Studie zur Landschaftsgenese im Raum Nordbarnim und Eberswalder Urstromtal. - Berliner Geographische Arbeiten, 76: $1-145$.

SchlaAk, N. (1998): Der Finowboden - Zeugnis einer begrabenen weichselspätglazialen Oberfläche in den Dünengebieten Nordostbrandenburgs. - Münchener Geographische Abhandlungen, Reihe A, Band A49: $143-148$

SchlaAk, N. (1999): Typical aeolian sand profiles and palaeosols of the Glien till plain in the northwest of Berlin. - In: SCHIRMER, W. (ed.): Dunes and fossil soils. - GeoArchaeoRhein, 3: 97-105; Münster (LIT).

Stuiver, M., Reimer, P.J. \& Reimer, R.W. (2005). CALIB 5.0 [www program and documentation]

STÜTZER, A. (1998): Early stages of podzolisation in young aeolian sediments, western Jutland. - Catena, 32: 115-129.

Teschner-Steinhardt, R. $\mho$ Müller, M. (1994): Zur Genese und dem Alter der Dünen im Bereich der Havel-Niederung, Berlin-Tegeler Forst. - Die Erde, 125: 123-138.

VANDENBerghe, J. (1985): Paleoenvironment and stratigraphy during the Last Glacial in the Belgian-Dutch Border Region. - Quaternary Research, 24: 23-38. 